\title{
Effect of Pre-Harvest Organic Cytokinin Application on the Post-Harvest Physiology of Pepper (Capsicum annuum L.)
}

\author{
Seyda Cavusoglu ${ }^{1}$, Suat Sensoy ${ }^{1}$, Arzu Karatas ${ }^{2}$, Onur Tekin ${ }^{1}$, Firat Islek ${ }^{3}$, Nurettin Yilmaz ${ }^{4}$, Selma Kipcak ${ }^{5}$, \\ Sezai Ercisli ${ }^{6} \mathbb{D}$, Sona Skrovankova ${ }^{7}{ }^{\mathbb{D}}$, Anna Adamkova ${ }^{7, *}{ }^{\mathbb{D}}$ and Jiri Mlcek ${ }^{7}$ \\ 1 Department of Horticulture, Faculty of Agriculture, Yuzuncu Yil University, Van 65080, Turkey; \\ scavusoglu77@gmail.com (S.C.); suatsensoy@yyu.edu.tr (S.S.); onurtekin@yyu.edu.tr (O.T.) \\ 2 Department of Horticulture, Faculty of Horticulture, Recep Tayyip Erdogan University, Pazar, \\ Rize 53800, Turkey; arzu.karatas@erdogan.edu.tr \\ 3 Department of Plant and Production Technologies, Faculty of Applied Sciences, Mus Alparslan University, \\ Mus 49250, Turkey; f.islek@alparslan.edu.tr \\ 4 Institute of Natural and Applied Sciences, Yuzuncu Yil University, Van 65080, Turkey; nrtnylmz47@gmail.com \\ 5 Department of Organic Agriculture, Baskale Vocational School, Yuzuncu Yil University, Baskale, \\ Van 65140, Turkey; selmakipcak@yyu.edu.tr \\ 6 Department of Horticulture, Faculty of Agriculture, Ataturk University, Erzurum 25240, Turkey; \\ sercisli@gmail.com \\ 7 Department of Food Analysis and Chemistry, Faculty of Technology, Tomas Bata University in Zlin, \\ Vavreckova 275, CZ-76001 Zlin, Czech Republic; skrovankova@utb.cz (S.S.); mlcek@utb.cz (J.M.) \\ check for \\ updates \\ * Correspondence: aadamkova@utb.cz; Tel.: +420-576-033-030
}

Citation: Cavusoglu, S.; Sensoy, S.; Karatas, A.; Tekin, O.; Islek, F.; Yilmaz, N.; Kipcak, S.; Ercisli, S.; Skrovankova, S.; Adamkova, A.; et al. Effect of Pre-Harvest Organic Cytokinin Application on the Post-Harvest Physiology of Pepper (Capsicum annuum L.). Sustainability 2021, 13, 8258. https://doi.org/ $10.3390 /$ su13158258

Academic Editor:

Anastasios Michailidis

Received: 24 June 2021

Accepted: 20 July 2021

Published: 23 July 2021

Publisher's Note: MDPI stays neutral with regard to jurisdictional claims in published maps and institutional affiliations.

Copyright: (c) 2021 by the authors Licensee MDPI, Basel, Switzerland. This article is an open access article distributed under the terms and conditions of the Creative Commons Attribution (CC BY) license (https:// creativecommons.org/licenses/by/ $4.0 /)$.

\begin{abstract}
Peppers are cultivated in almost all provinces in Turkey, making up approximately 7\% of the world's production. In this study, the effects of pre-harvest cytokinin application on the postharvest physiology of pepper (Capsicum annuum L.) fruits (cv. Akra and Melek F1) grown in ecological conditions in Turkey (Van, eastern Turkey) were investigated. During the growing period, organic cytokinin(nytrozine) at two concentrations (50 and $100 \mathrm{ppm}$ doses) was applied by spraying. Peppers were harvested in green maturity and then stored at $12{ }^{\circ} \mathrm{C}$ for 28 days. Changes in color, respiration rate, exogenous ethylene amount, antioxidative enzyme analysis (SOD, CAT and APX), lipid peroxidation, total phenolic content (TP) and antioxidant activity (AA) were determined just after the harvest and then at the 7th, 14th, 24th and 28th days. $\mathrm{L}^{*}$ values for both varieties and the control sample had fluctuations during storage, and they slightly decreased after 28 days, except for the end value of cv. Melek F1 with a 50 ppm addition. In terms of respiration rate values, the difference between applications was found to be statistically significant, except for the 14th and 24th days of storage, for cv. Akra F1; and the 0th and 28th days for cv. Melek F1, respectively. It was observed that cytokinin can delay aging in peppers of both cultivars stored for 28 days. As a result, as the used cytokinin has an organic origin, is not synthetic and does not have a negative effect on human health, it can be used safely and without a significant loss of quality characteristics for peppers. These applications have positive effects on in-package gas composition, antioxidative enzymes, lipid peroxidation, total phenolics and total antioxidant activity.
\end{abstract}

Keywords: pepper; storage; cytokinin; antioxidative enzyme; respiration; bioactive content

\section{Introduction}

Horticulture is practiced across cool temperate to tropical latitudes and over a wide range of elevations and climatic conditions. Horticultural products include all products, raw or processed, that arise from the horticultural industry. Horticulture plants, including pepper, have recently gained popularity [1-3]. They include a high content of non-nutritive, nutritive and bioactive compounds such as flavonoids, phenolics, anthocyanins and phenolic acids, as well as nutritive compounds such as sugars, essential oils, carotenoids, 
vitamins and minerals. They also have a distinct flavor and taste, excellent medicinal value and health care functions $[4,5]$.

Peppers (Capsicum annuum L.) belong to the Capsicum genus of the Solanaceae family. They have a different fruit color, from yellow to green and red, and are preferred due to their sensory qualities (taste, aroma and color) $[1,6]$. They are mainly used for fresh consumption, in salads, and also in cooked foods [3,7]. Peppers belong to the crops that have an important place in human nutrition as a good source of essential vitamins and many beneficial antioxidants, such as carotenoids, flavonoids and phenolic acids [8,9]. The Akra and Melek F1 hybrid pepper varieties have been very popular lately and the object of a wide economic growth in Turkey.

In recent years, the demand for pepper production has increased due to its commercial value and great market usage worldwide [10]. Turkey, with a production of about 2.5 million tons of peppers, is the third greatest producer in the world, after China and Mexico [11].

Changes in physiological activities, the loss of nutrients and a rapid physical and physiological decomposition are common post-harvest problems for the pepper market [12], with softening, drying and fungal spoilage as the main difficulties [13].

Methods that are effective in reducing weight loss in peppers, due to water loss, use a stretch film [14], a modified atmosphere packaging (MAP) [15], a controlled atmosphere (CA) storage [16] and a new system, Palistore (the storage of palletized goods under CA) [17]. Post-harvest studies on peppers proved that MAP is an effective way of maintaining the quality and extending the storage life of plant-based products $[18,19]$.

Today, one of the greatest challenges faced by the agriculture and food industries is developing sustainable and environmentally friendly systems to meet the nutritional demand of the continuously growing global population. One of the solutions that would enable producers to increase crop yields and protect produce is the implementation of eco-friendly treatments [20-23].

Cytokinin, an essential plant hormone, has both organic and synthetic forms which are known to have an important effect on preventing post-harvest aging. The external application of cytokinin to the plant causes a delay in aging, the breaking of apical dormancy, an increase of chlorophyll production and an encouragement to chloroplast development, a decrease in chlorophyll degradation, the support of protein and nucleic acid synthesis, the transport of nutrients to the area where the cytokine is applied and the maintenance of photosynthetic activity [24]. Moreover, gibberellins, belonging to a major class of plant hormones, and cytokinin have been reported to be effective in plant development and maturation [25]. It was also reported that post-harvest 6-benzylaminopurine (BAP) application preserves product quality, prevents rotting and extends shelf life [26].

The aim of this study is to determine the effect of pre-harvest cytokinin applications (50 and 100 ppm doses) on two hybrid pepper cultivars (cv. Akra F1 and cv. Melek F1), grown at field conditions in eastern Turkey (Van province) and to reveal the impact on physical and biochemical changes during storage.

\section{Materials and Methods}

\subsection{Material}

Green peppers for analyses were planted from the seedlings of two hybrid pepper cultivars (cv. Akra F1 and cv. Melek F1) in an unheated glass greenhouse of Van Yüzüncü Yll University (eastern Turkey) at a row distance of $30 \times 30 \mathrm{~cm}$. Pepper plants were irrigated with a drip irrigation system. When the peppers reached the first fruit set stage, pre-harvest organic cytokinin (nytrozine) was applied. Control (0 ppm), $50 \mathrm{ppm}$ and $100 \mathrm{ppm}$ doses of cytokinin were sprayed on the peppers. The application has been made at sunset to prevent cytokinin from being affected by sunlight. Cytokinin doses are based on previous studies of vegetables [27].

Green peppers were harvested ( $2 \mathrm{~kg}$ of each cultivar) and kept at room conditions $\left(18 \pm 2{ }^{\circ} \mathrm{C}\right)$ for $24 \mathrm{~h}$; the internal temperature of the pepper fruits was reduced, and then 
the fruits were placed on a foam plate, covered with stretch foil and stored for 28 days in a cold place at $12{ }^{\circ} \mathrm{C}$ and $90-95 \%$ relative humidity.

\subsection{Methods}

All analyses were performed in three replications, and at five storage times (freshly harvested (0 day), 7th, 14th, 24th and 28th day).

\subsubsection{Color}

The changes in the color values of the peppers were determined by a Minolta CR-400 brand colorimeter. The results are expressed as $\mathrm{L}^{*}, \mathrm{a}^{*}, \mathrm{~b}^{*} \mathrm{C}$ and Hue angle value. Colors represent the color values, $\mathrm{a}^{*}$ (+red,-green), $\mathrm{b}^{*}$ (+yellow, - blue) and $\mathrm{L}^{*}$ (brightness).

\subsubsection{Respiratory Rate}

For the evaluation of the respiration rates, the pepper fruits were placed in gastight containers, and the amount of $\mathrm{CO}_{2}$ given to the environment at the end of $2 \mathrm{~h}$ was determined with the Headspace Gas Analyzer GS3/L analyzer device (Systech Inst., Gaspace Advance, GS3/L; Johnsburg, IL, USA). Respiratory rate values were calculated using the weight and volume values [27].

\subsubsection{Exogenous Ethylene Content}

In the determination of the exogenous ethylene amount of the pepper fruits, the samples were placed in a gas-tight container and, after a 2-h waiting period, the gas samples were injected into the Gas Chromatography (GC) device (Shimadzu, Kyoto, Japan) equipped with a flame ionization detector (FID) and a stainless Restek Rt-Alumina BOND/MAPD 50m, 0.53mm ID, filled with activated alumina. The temperatures of the oven and FID detectors were $40^{\circ} \mathrm{C}$ (isothermal) and $250{ }^{\circ} \mathrm{C}$, respectively. The gas flows for high-purity hydrogen $\left(\mathrm{H}_{2}\right)$ and dry air used as carrier gas in FID were 30 and $400 \mathrm{~mL}$ $\mathrm{min}^{-1}$, respectively. The formula used for calculating the respiratory rate was modified [27] and calculated as $\mathrm{ml} \mathrm{C}_{2} \mathrm{H}_{4} \mathrm{kgh}^{-1}$.

\subsubsection{In-Package Gas Composition}

The $\mathrm{CO}_{2}$ and $\mathrm{O}_{2}$ gas levels in the packages of peppers were determined with the Headspace Gas Analyzer GS3/L device (Johnsburg, IL, USA) Missing manufacturer's brand, producer, conditions and unit expression).

\subsubsection{Antioxidative Enzyme Analysis (SOD, CAT and APX)}

SOD activity was determined by the inhibition of nitroblue tetrazolium (NBT) at $560 \mathrm{~nm}$ wavelength [24] (Thermo Scientific Genesys 10S Model UV-VIS spectrophotometer Waltham, MA, USA). For the determination of CAT activity, 0 and $60 \mathrm{~s}$ readings were taken at a $240 \mathrm{~nm}$ wavelength in the spectrophotometer. The evaluation was made considering the change in absorbance within 1 min [24] (Evolution ${ }^{\mathrm{TM}}$ 201/220 UV-Visible Spectrophotometers, USA). APX activity was measured by the reduction of the $\mathrm{H}_{2} \mathrm{O}_{2}$ bound to ascorbic acid at a $290 \mathrm{~nm}$ wavelength. At 0 and $60 \mathrm{~s}$, readings were taken at a $290 \mathrm{~nm}$ wavelength in the spectrophotometer (Thermo Scientific Genesys $10 \mathrm{~S}$ Model, Waltham, MA, USA). This was performed considering the change in absorbance within $1 \mathrm{~min}$ [28].

\subsubsection{Lipid Peroxidation}

Lipid peroxidation in plants is expressed as malondialdehyde (MDA) content. The MDA content of the pepper samples was determined by reading the absorbance values at 532 and $600 \mathrm{~nm}$ wavelengths [29] (Thermo Scientific Genesys 10S Model, Madison, WI, USA). 


\subsubsection{Total Phenolic Content and Antioxidant Activity}

The total phenolic content (TP) of peppers was determined spectrophotometrically (Thermo Scientific Genesys 10S Model, Waltham, MA, USA) using the Folin-Ciocalteu colorimetric method [30]. The absorbances of the solutions were read at a wavelength of $700 \mathrm{~nm}$ by the spectrophotometer, with gallic acid as a standard. The amount of TP was expressed as gallic acid equivalents (GAE) at $\mathrm{mg} 100 \mathrm{~g}^{-1}$ fresh weight (FW).

To determine the antioxidant activity (AA), the FRAP (Ferric Reducing Antioxidant Power) method was used [31]. Absorbances of the solutions were read at a wavelength of $593 \mathrm{~nm}$ by the spectrophotometer (Thermo Scientific Genesys 10S Model UV-VIS spectrophotometer, Waltham, MA, USA). AA values were given due to the Trolox standard, as $\mu$ mol trolox equivalent (TE) $\mathrm{g}^{-1}$.

\subsubsection{Statistical Analysis}

Descriptive statistics for the traits were expressed as average and standard deviations. A one-way analysis of variance was performed in factorial order to determine whether there was a difference between applications and storage times. Following the variance analysis, a Duncan test was used to determine the difference between the mean of applications and storage times. The statistical significance level was taken as $5 \%$ in the calculations, and the "SPSS version 13.0" statistics package program was used for the calculations.

\section{Results and Discussion}

\subsection{Color}

The color of peppers is one of the most important parameters for consumer acceptability that also affects their marketability $[17,32]$. Color values are expressed as $\mathrm{L}^{*}, \mathrm{a}^{*}$, $b^{*}, C$ and Hue angle value. The color parameter $L^{*}$ ranges from 0 up to 100; and when it approaches 100 , the brightness increases. Hue is the color quality that distinguishes one color from another: a hue angle of $0^{\circ}$ indicates red, $90^{\circ}$ yellow, $180^{\circ}$ green and $270^{\circ}$ blue. The chroma value expresses the vividness and dullness of fruits and vegetables. A low chroma value indicates a dull color, while an increase in this value indicates a vivid color.

The changes in color values of cv. Akra F1 and cv. Melek F1 pepper cultivars after cytokinin application during 28 days storage were examined and are shown in Table 1 . It was determined that the $\mathrm{L}^{*}$ values for both varieties and the control sample had fluctuations during storage, and they slightly decreased after 28 days, except for the end value of $\mathrm{cv}$. Melek F1 with 50 ppm addition. Çavuşoğlu and Gökçenay [17] stated that the $\mathrm{L}^{*}$ value of mushrooms treated with cytokinin was better than that of the control; however, they attributed this to tissue aging. Color change is closely related to the ripening process, and is one of the indicators of physical and chemical development stages $[9,33,34]$. In terms of the $L^{*}$ value results (Table 1), there were similarities with other studies; as for bananas [25], olives [35] and mushrooms [17], the $\mathrm{L}^{*}$ color value of cv. Akra F1 was found to be statistically significant in terms of storage times except for the 0th and 28th days of storage, while for $\mathrm{cv}$. Melek F1 they were found to be statistically significant only at the 28 th day of storage. The difference between both cultivars in terms of all application and storage times was found to be statistically significant (Table 1). 
Table 1. Changes in the colors $\left(\mathrm{L}^{*}, \mathrm{a}^{*}, \mathrm{~b}^{*}, \mathrm{C}^{\circ}\right.$ and $\mathrm{H}^{\circ}$ ) of pepper fruits cultivars (cv. Akra F1 and cv. Melek F1) treated with two concentrations of cytokinin during storage.

\begin{tabular}{|c|c|c|c|c|c|c|c|}
\hline & \multirow[b]{2}{*}{$\begin{array}{c}\text { Storage } \\
\text { Period (Day) }\end{array}$} & \multicolumn{3}{|c|}{ cv. Akra F1 } & \multicolumn{3}{|c|}{ cv. Melek F1 } \\
\hline & & Control & $50 \mathrm{ppm}$ & 100 ppm & Control & $50 \mathrm{ppm}$ & 100 ppm \\
\hline \multirow{5}{*}{$\mathbf{L}^{*}$} & 0 & $51.90 \pm 0.59 \mathrm{~A} \mathrm{ab} \#$ & $47.80 \pm 0.23 \mathrm{~B} \mathrm{a} \mathrm{\#}$ & $47.73 \pm 0.45 \mathrm{~B}$ a \# & $65.42 \pm 0.23 \mathrm{~A} \mathrm{a}$ & $65.11 \pm 0.65 \mathrm{~A} \mathrm{ab}$ & $66.10 \pm 0.04 \mathrm{~A} \mathrm{a}$ \\
\hline & 7 & $47.77 \pm 0.89 \mathrm{~A} \mathrm{~b} \#$ & $46.29 \pm 0.71 \mathrm{~A} \mathrm{a} \mathrm{\#}$ & $47.40 \pm 0.84 \mathrm{~A} \mathrm{a} \mathrm{\#}$ & $62.99 \pm 2.59 \mathrm{~A} \mathrm{a}$ & $62.66 \pm 0.96 \mathrm{~A} \mathrm{~b}$ & $64.18 \pm 0.81 \mathrm{~A} \mathrm{ab}$ \\
\hline & 14 & $52.30 \pm 1.67 \mathrm{~A} \mathrm{a} \mathrm{\#}$ & $45.58 \pm 0.75 \mathrm{~B} \mathrm{a} \mathrm{\#}$ & $46.15 \pm 1.71 \mathrm{~B} \mathrm{ab} \#$ & $64.18 \pm 0.53 \mathrm{~A} \mathrm{a}$ & $64.39 \pm 0.68 \mathrm{~A} \mathrm{~b}$ & $63.21 \pm 1.06 \mathrm{~A} \mathrm{~b}$ \\
\hline & 24 & $48.61 \pm 1.79 \mathrm{~A} \mathrm{ab} \#$ & $46.38 \pm 1.12 \mathrm{AB}$ a\# & $43.64 \pm 1.06 \mathrm{~B} \mathrm{~b} \#$ & $65.23 \pm 1.27 \mathrm{~A} \mathrm{a}$ & $62.97 \pm 0.78 \mathrm{~A} \mathrm{~b}$ & $64.96 \pm 0.60 \mathrm{~A} \mathrm{ab}$ \\
\hline & 28 & $48.43 \pm 1.20 \mathrm{~A} \mathrm{ab} \#$ & $47.09 \pm 0.75 \mathrm{~A} \mathrm{a} \mathrm{\#}$ & $47.47 \pm 0.99 \mathrm{~A} \mathrm{a} \mathrm{\#}$ & $65.26 \pm 0.29 \mathrm{~B}$ & $67.31 \pm 0.78 \mathrm{~A} \mathrm{a}$ & $65.690 .224 \mathrm{AB}$ a \\
\hline \multirow{5}{*}{$a^{*}$} & 0 & $-20.72 \pm 0.03 \mathrm{~B} \mathrm{~b} \#$ & $-19.30 \pm 0.31 \mathrm{~A} \mathrm{~b} \#$ & $-19.06 \pm 0.06 \mathrm{~A} \mathrm{~b} \#$ & $-16.89 \pm 0.09 \mathrm{~A} \mathrm{~b}$ & $-17.62 \pm 0.29 \mathrm{~A} \mathrm{~b}$ & $-17.30 \pm 0.24 \mathrm{Ab}$ \\
\hline & 7 & $-18.25 \pm 0.43 \mathrm{~A} \mathrm{a} \mathrm{\#}$ & $-19.23 \pm 0.22 \mathrm{~A} \mathrm{~b} \#$ & $-18.89 \pm 0.30 \mathrm{~A} \mathrm{~b} \#$ & $-15.64 \pm 0.45 \mathrm{~A} \mathrm{ab}$ & $-16.47 \pm 0.93 \mathrm{~A} \mathrm{~b}$ & $-16.52 \pm 0.20 \mathrm{Abc}$ \\
\hline & 14 & $-18.82 \pm 0.55 \mathrm{~A} \mathrm{a} \#$ & $-17.59 \pm 0.60 \mathrm{~A} \mathrm{a}$ & $-18.08 \pm 0.75 \mathrm{~A} \mathrm{~b} \#$ & $-16.34 \pm 0.34 \mathrm{~A} \mathrm{ab}$ & $-16.09 \pm 0.24 \mathrm{~A} \mathrm{~b}$ & $-15.63 \pm 0.33 \mathrm{~A} \mathrm{ab}$ \\
\hline & 24 & $-17.38 \pm 0.72 \mathrm{~A} \mathrm{a}$ & $-17.88 \pm 0.61 \mathrm{~A} \mathrm{a}$ & $-16.38 \pm 0.12 \mathrm{~A} \mathrm{a}$ & $-15.35 \pm 0.58 \mathrm{~A} \mathrm{a}$ & $-16.30 \pm 0.25 \mathrm{~A} \mathrm{~b}$ & $-15.67 \pm 0.51 \mathrm{~A} \mathrm{ab}$ \\
\hline & 28 & $-17.40 \pm 0.44 \mathrm{~A} \mathrm{a} \mathrm{\#}$ & $-17.88 \pm 0.21 \mathrm{~A} \mathrm{a} \mathrm{\#}$ & $-17.88 \pm 0.18 \mathrm{~A} \mathrm{~b} \#$ & $-15.49 \pm 0.50 \mathrm{~B}$ ab & $-14.10 \pm 0.12 \mathrm{~A} \mathrm{a}$ & $-15.03 \pm 0.28 \mathrm{AB}$ \\
\hline \multirow{2}{*}{\multicolumn{8}{|c|}{$\begin{array}{c}\text { Significiant effects; Ptreatment: } 0.253 \text { Pstorege: } 0.001 \text { Ptreatment } \times \text { Pstorege: } 0.001 \text { Ptreatment: } 0.799 \text { Pstorege: } 0.001 \text { Ptreatment } \times \text { Pstorege: } 0.126 \\
\text { Significiant effects; Pcv: } 0.001 \text { Pcv } \times \text { Ptreatment: } 0.361 \text { Pcv } \times \text { Pstorage: } 0.061 \text { Pcv } \times \text { Ptreatment } \times \text { Pstorage: } 0.075\end{array}$}} \\
\hline & & & & & & & \\
\hline \multirow{4}{*}{$\mathbf{b}^{*}$} & 7 & $38.59 \pm 0.55 \mathrm{~A} \mathrm{a}$ & $33.73 \pm 0.48 \mathrm{~B} \mathrm{~b} \#$ & $34.60 \pm 0.55 \mathrm{~B}$ ab \# & $37.36 \pm 0.74 \mathrm{~A} \mathrm{~b}$ & $39.38 \pm 1.62 \mathrm{~A} \mathrm{bc}$ & $38.57 \pm 0.60 \mathrm{~A} \mathrm{~b}$ \\
\hline & 14 & $39.70 \pm 1.52 \mathrm{~A} \mathrm{a}$ & $34.64 \pm 0.93 \mathrm{~B} \mathrm{ab} \#$ & $34.83 \pm 1.01 \mathrm{~B} \mathrm{ab}$ & $38.71 \pm 0.84 \mathrm{~A} \mathrm{ab}$ & $39.40 \pm 0.99 \mathrm{~A} \mathrm{bc}$ & $37.05 \pm 0.99 \mathrm{~A} \mathrm{~b}$ \\
\hline & 24 & $38.50 \pm 1.38 \mathrm{~A} \mathrm{a}$ & $37.30 \pm 1.04 \mathrm{~A} \mathrm{a}$ & $33.07 \pm 1.03 \mathrm{~B} \mathrm{~b} \#$ & $38.04 \pm 0.93 \mathrm{~A} \mathrm{ab}$ & $40.28 \pm 0.34 \mathrm{~A} \mathrm{ab}$ & $38.46 \pm 0.54 \mathrm{~A} \mathrm{~b}$ \\
\hline & 28 & $39.56 \pm 1.27 \mathrm{~A} \mathrm{a}$ & $36.11 \pm 1.55 \mathrm{~A} \mathrm{ab}$ & $36.32 \pm 0.51 \mathrm{~A} \mathrm{a}$ & $38.65 \pm 0.76 \mathrm{~A} \mathrm{ab}$ & $36.92 \pm 0.18 \mathrm{~A} \mathrm{c}$ & $37.43 \pm 0.35 \mathrm{~A} \mathrm{~b}$ \\
\hline \multicolumn{8}{|c|}{$\begin{array}{l}\text { Significiant effects; Ptreatment: } 0.001 \text { Pstorege: } 0.347 \text { Ptreatment } \times \text { Pstorege: } 0.179 \text { Ptreatment: } 0.040 \text { Pstorege: } 0.001 \text { Ptreatment } \times \text { Pstorege: } 0.173 \\
\text { Significiant effects; Pcv: } 0.001 \text { Pcv } \times \text { Ptreatment: } 0.001 \text { Pcv } \times \text { Pstorage: } 0.001 \text { Pcv } \times \text { Ptreatment } \times \text { Pstorage: } 0.169\end{array}$} \\
\hline \multirow{5}{*}{$\mathbf{C}^{*}$} & 0 & $45.41 \pm 0.70 \mathrm{~A} \mathrm{a}$ & $39.87 \pm 0.59 \mathrm{~B} \mathrm{a} \mathrm{\#}$ & $38.78 \pm 0.13 \mathrm{~B} \mathrm{a} \mathrm{\#}$ & $43.72 \pm 0.25 \mathrm{~B} \mathrm{a}$ & $45.89 \pm 0.31 \mathrm{~A} \mathrm{a}$ & $44.43 \pm 0.64 \mathrm{AB} \mathrm{a}$ \\
\hline & 7 & $42.75 \pm 0.65 \mathrm{~A} \mathrm{a}$ & $38.83 \pm 0.51 \mathrm{~B} \mathrm{a}$ & $39.44 \pm 0.62 \mathrm{~B} \mathrm{a} \mathrm{\#}$ & $40.51 \pm 0.86 \mathrm{~A} \mathrm{~b}$ & $42.69 \pm 1.85 \mathrm{~A} \mathrm{~b}$ & $41.97 \pm 0.62 \mathrm{~A} \mathrm{~b}$ \\
\hline & 14 & $43.96 \pm 1.49 \mathrm{~A} \mathrm{a}$ & $38.90 \pm 1.06 \mathrm{~B} \mathrm{a}$ & $39.28 \pm 1.22 \mathrm{~B} \mathrm{a}$ & $41.93 \pm 0.87 \mathrm{~A} \mathrm{ab}$ & $42.57 \pm 1.00 \mathrm{~A} \mathrm{~b}$ & $40.22 \pm 1.03 \mathrm{~A} \mathrm{~b}$ \\
\hline & 24 & $42.29 \pm 1.54 \mathrm{~A} \mathrm{a}$ & $41.37 \pm 1.19 \mathrm{~A} \mathrm{a}$ & $37.00 \pm 0.97 \mathrm{~B}$ a \# & $41.03 \pm 1.08 \mathrm{~A} \mathrm{ab}$ & $43.46 \pm 0.40 \mathrm{~A} \mathrm{ab}$ & $41.55 \pm 0.69 \mathrm{~A} \mathrm{~b}$ \\
\hline & 28 & $43.34 \pm 1.08 \mathrm{~A} \mathrm{a}$ & $40.33 \pm 1.40 \mathrm{~A} \mathrm{a}$ & $28.49 \pm 1.30 \mathrm{~B} \mathrm{a}$ & $41.65 \pm 0.89 \mathrm{~A} \mathrm{ab}$ & $39.53 \pm 0.20 \mathrm{~B} \mathrm{C}$ & $40.36 \pm 0.43 \mathrm{AB} \mathrm{b}$ \\
\hline
\end{tabular}

Significiant effects; Ptreatment: 0.010 Pstorege: 0.643 Ptreatment $\times$ Pstorege: 0.631 Ptreatment: 0.080 Pstorege: 0.001 Ptreatment $\times$ Pstorege: 0.158 Significiant effects; Pcv: 0.021 Pcv $\times$ Ptreatment: 0.008 Pcv $\times$ Pstorage: 0.878 Pcv $\times$ Ptreatment $\times$ Pstorage: 0.545 
Table 1. Cont.

\begin{tabular}{ccccc} 
cv. Akra F1 & \multicolumn{3}{c}{ cv. Melek F1 } \\
$119.5 \pm 0.29 \mathrm{~A} \mathrm{a} \mathrm{\#}$ & $119.5 \pm 0.19 \mathrm{~A} \mathrm{a} \mathrm{\#}$ & $112.7 \pm 0.03 \mathrm{~A} \mathrm{a}$ & $112.5 \pm 0.28 \mathrm{~A} \mathrm{a}$ & $112.8 \pm 0.02 \mathrm{~A} \mathrm{~b}$ \\
$119.7 \pm 0.18 \mathrm{~A} \mathrm{a} \mathrm{\#}$ & $118.7 \pm 0.13 \mathrm{~B} \mathrm{a} \mathrm{\#}$ & $112.5 \pm 0.26 \mathrm{~A} \mathrm{a}$ & $112.6 \pm 0.36 \mathrm{~A} \mathrm{a}$ & $113.1 \pm 0.19 \mathrm{~A} \mathrm{a}$ \\
$6.76 \pm 0.39 \mathrm{AB} \mathrm{b} \#$ & $117.5 \pm 0.40 \mathrm{~A} \mathrm{ab} \#$ & $112.9 \pm 0.09 \mathrm{~A} \mathrm{a}$ & $112.1 \pm 0.16 \mathrm{~A} \mathrm{a}$ & $112.8 \pm 0.18 \mathrm{~A} \mathrm{~b}$ \\
$15.6 \pm 0.29 \mathrm{~A} \mathrm{~b} \#$ & $116.1 \pm 1.50 \mathrm{~A} \mathrm{~b}$ & $111.9 \pm 0.26 \mathrm{~A} \mathrm{~b}$ & $112.0 \pm 0.164 \mathrm{~A} \mathrm{a}$ & $112.1 \pm 0.42 \mathrm{~A} \mathrm{~b}$ \\
$16.5 \pm 0.97 \mathrm{~A} \mathrm{~b} \#$ & $116.2 \pm 0.30 \mathrm{~A} \mathrm{~b} \#$ & $111.7 \pm 0.24 \mathrm{~A} \mathrm{~b}$ & $110.86 \pm 0.15 \mathrm{~A} \mathrm{~b}$ & $111.8 \pm 0.19 \mathrm{~A} \mathrm{c}$ \\
\hline
\end{tabular}

Significiant effects; Ptreatment: 0.001 Pstorege: 0.001 Ptreatment $x$ Pstorege: 0.309 Ptreatment: 0.004 Pstorege: 0.001 Ptreatment $\times$ Pstorege: 0.313 Significiant effects; Pcv: 0.001 Pcv $\times$ Ptreatment: 0.001 Pcv $\times$ Pstorage: 0.001 Pcv $\times$ Ptreatment $\times$ Pstorage: 0.438

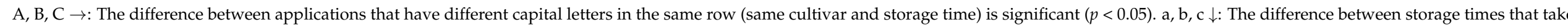
different lower-case letters in the same column (same cultivar and application) is significant $(p<0.05)$. \#: The difference from cv. Melek F1 in the same application and storage time is significant ( $p<0.05)$.
} 
The $\mathrm{a}^{*}$ values of both pepper cultivars and the control were found to increase, again with fluctuations. It was seen that the $\mathrm{a}^{*}$ color values in the samples treated with cytokinin were lower compared to the control. The highest a values were especially near the end of storage (24th or 28th day), and higher for cv. Melek F1, while the highest was for the $50 \mathrm{ppm}$ cytokinin application. In several studies about broccoli, it was determined that the samples treated with cytokinin preserved the green color better. It was found that the application of cytokinin was related to the delay of chlorophyll degradation [24,36,37]. As for the $a^{*}$ color value in this study, there were significant variances in terms of the difference between applications for the same variety and storage time for the 0th day of storage in cv. Akra F1 and the 28th day of storage in cv. Melek F1. The values of cv. Akra F1 were significantly different from those of cv. Melek F1, except for the 14th and 24th days of storage after a 50 ppm cytokine application, and the 24th day of storage after a 50 ppm cytokine application (Table 1 ).

As for $b^{*}$ color values during storage, we found an increase with fluctuations for cv. Akra F1, except for the control group, but there was a decrease with fluctuations for Melek F1 during 28 days of storage. There was a difference in $b^{*}$ values between cv. Akra F1 and cv. Melek F1. Statistically, $b^{*}$ values were found to be significantly different for samples with applications in the storage period, except for the 28th day of storage in cv. Akra F1 and the 0th day in cv. Melek F1. The obtained data were similar to Al-Qurashi and Awad's [25] study on bananas.

As the chroma value indicates the vividness and dullness of the fruit or skin color, it has been found that the chroma value will be low in dull colors and high in vivid colors [38]. Chroma values in peppers were found to decrease during storage in both cultivars, except in the end of storage for cv. Akra F1 with 50 ppm addition. The applications of cytokinin thus slowed the pepper maturation. Moreover, a slight fluctuation was observed. Especially for some cultivars, the increase in the chroma value is seen as a typical ripening event $[39,40]$. All storage times for cv. Akra F1, and the 0th and 28th days of storage in cv. Melek F1 were found to be statistically significant in terms of differences between applications. The difference between the storage of cv. Akra F1 on the 0th day in the application of $50 \mathrm{ppm}$ cytokinin and the 0 th, 7 th and 24th days in the cytokinin application of 100 ppm from cv. Melek F1 was found to be statistically significant (Table 1).

While the hue value expresses the angle of the line passing through the point where the $\mathrm{a}^{*}$ and $\mathrm{b}^{*}$ color values intersect the $\mathrm{X}$ axis, it is known that the angle corresponds to red when $0^{\circ}$, yellow when $90^{\circ}$, green when $180^{\circ}$ and blue when $270^{\circ}$. Hue color values for peppers were found to decrease during storage for both cultivars. The hue values of the samples treated with cytokinin, compared to the control, were higher for both pepper cultivars. The aging of the control group samples is faster than that of the samples treated with cytokinin. The results obtained in the present study are similar to those of Downs et al. [37] for broccoli and Tsantili et al. [35] for olives. For cv. Akra F1, the difference between applications in storage periods, except for the 24th day of storage, was found to be statistically significant. The difference between the applications was not statistically significant in cv. Melek F1. For cv. Akra F1, there were significant differences from cv. Melek F1, except for the 24th day of storage, at 100 ppm cytokine addition (Table 1).

\subsection{Respiratory Rate}

As for the significance of respiration on the shelf life, Lee et al. [41] pointed out that there exists an inverse relationship between the respiration rate and shelf life. In our study, there were differences in the respiration rate of pepper fruits belonging to both cultivars (cv. Akra F1 and cv. Melek F1) during the storage periods (Table 2). 


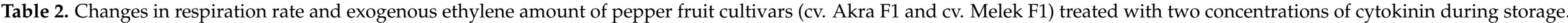

\begin{tabular}{|c|c|c|c|c|c|c|c|}
\hline & \multirow[b]{2}{*}{$\begin{array}{l}\text { Storage Period } \\
\text { (Day) }\end{array}$} & \multicolumn{3}{|c|}{ Akra F1 } & \multicolumn{3}{|c|}{ Melek F1 } \\
\hline & & Control & $50 \mathrm{ppm}$ & 100 ppm & Control & $50 \mathrm{ppm}$ & $100 \mathrm{ppm}$ \\
\hline \multirow{5}{*}{$\begin{array}{l}\text { Respiration Rate } \\
(\mathrm{mL} \mathrm{CO} / \mathrm{kgh})\end{array}$} & 0 & $111.2 \pm 1.78$ А с \# & $96.6 \pm 1.08 \mathrm{~B} \mathrm{~b} \#$ & $56.8 \pm 0.00 \mathrm{Cc} \#$ & $88.3 \pm 3.03 \mathrm{~B} \mathrm{a}$ & $118.8 \pm 2.85 \mathrm{~A} \mathrm{a}$ & $81.5 \pm 2.85 \mathrm{~B} \mathrm{ab}$ \\
\hline & 7 & $139.6 \pm 6.18 \mathrm{~A} \mathrm{bc} \#$ & $127.8 \pm 3.66 \mathrm{~A} \mathrm{~b} \#$ & $90.7 \pm 9.83$ B b \# & $48.6 \pm 3.85 \mathrm{~A} \mathrm{~b}$ & $64.1 \pm 5.28 \mathrm{~A} \mathrm{~b}$ & $57.2 \pm 7.07 \mathrm{~A} \mathrm{~b}$ \\
\hline & 14 & $198.9 \pm 14.00 \mathrm{~A} \mathrm{a} \mathrm{\#}$ & $188.1 \pm 16.98 \mathrm{~A} \mathrm{a} \mathrm{\#}$ & $166.0 \pm 8.45 \mathrm{~A}$ a \# & $73.8 \pm 2.33 \mathrm{~A} \mathrm{a}$ & $99.6 \pm 18.97 \mathrm{~A} \mathrm{a}$ & $89.7 \pm 4.18 \mathrm{~A} \mathrm{a}$ \\
\hline & 24 & $164.8 \pm 28.26 \mathrm{~A} \mathrm{ab} \#$ & $128.8 \pm 13.44 \mathrm{~A} \mathrm{~b} \#$ & $103.5 \pm 6.72 \mathrm{~A} \mathrm{~b}$ & $53.0 \pm 10.07 \mathrm{~A} \mathrm{~b}$ & $66.15 \pm 10.30 \mathrm{~A} \mathrm{~b}$ & $56.75 \pm 19.31 \mathrm{~A} \mathrm{~b}$ \\
\hline & 28 & $158.5 \pm 6.55 \mathrm{~A} \mathrm{abc} \#$ & $102.9 \pm 5.70 \mathrm{~B} \mathrm{~b}$ & $100.2 \pm 6.64 \mathrm{~B} \mathrm{~b} \#$ & $79.3 \pm 5.28 \mathrm{~A} \mathrm{a}$ & $60.3 \pm 3.35 \mathrm{~B} \mathrm{~b}$ & $57.7 \pm 3.59 \mathrm{~B} \mathrm{~b}$ \\
\hline
\end{tabular}

Significiant effects; Ptreatment: 0.001 Pstorege: 0.001 Ptreatment $\times$ Pstorege: 0.045 Ptreatment: 0.033 Pstorege: 0.001 Ptreatment $\times$ Pstorege: 0.136 Significiant effects; Pcv: 0.001 Pcv $\times$ Ptreatment: 0.001 Pcv $\times$ Pstorage: 0.001 Pcv $\times$ Ptreatment $\times$ Pstorage: 0.781

\begin{tabular}{|c|c|c|c|c|c|c|c|}
\hline & 0 & $0.121 \pm 0.01 \mathrm{~A} \mathrm{ab}$ & $0.046 \pm 0.02 \mathrm{~B} \mathrm{~b} \#$ & $0.012 \pm 0.00 \mathrm{Cb}$ & $0.088 \pm 0.02 \mathrm{~A} \mathrm{ab}$ & $0.103 \pm 0.01 \mathrm{~A} \mathrm{a}$ & $0.019 \pm 0.00 \mathrm{~B} \mathrm{C}$ \\
\hline Exogenous Ethylene & 7 & $0.092 \pm 0.01 \mathrm{~A} \mathrm{~b}$ & $0.086 \pm 0.03 \mathrm{~A} \mathrm{~b}$ & $0.057 \pm 0.01 \mathrm{~A} \mathrm{ab} \#$ & $0.0580 .03 \mathrm{~A} \mathrm{ab}$ & $0.107 \pm 0.04 \mathrm{~A} \mathrm{a}$ & $0.144 \pm 0.00 \mathrm{~A} \mathrm{a}$ \\
\hline Amount & 14 & $0.254 \pm 0.09 \mathrm{~A} \mathrm{a}$ & $0.293 \pm 0.08 \mathrm{~A} \mathrm{a} \mathrm{\#}$ & $0.084 \pm 0.04 \mathrm{~A} \mathrm{ab}$ & $0.080 \pm 0.02 \mathrm{~A} \mathrm{ab}$ & $0.046 \pm 0.00 \mathrm{AB} a b$ & $0.007 \pm 0.01 \mathrm{~B} \mathrm{C}$ \\
\hline$\left(\mathrm{mL} \mathrm{C}_{2} \mathrm{H}_{4} / \mathrm{kgh}\right)$ & 24 & $0.045 \pm 0.03 \mathrm{~A} \mathrm{~b}$ & $0.110 \pm 0.06 \mathrm{~A} \mathrm{~b}$ & $0.147 \pm 0.05 \mathrm{~A} \mathrm{a}$ & $0.030 \pm 0.01 \mathrm{~A} \mathrm{~b}$ & $0.023 \pm 0.01 \mathrm{~A} \mathrm{~b}$ & $0.039 \pm 0.01 \mathrm{~A} \mathrm{~b}$ \\
\hline & 28 & $0.072 \pm 0.02 \mathrm{~A} \mathrm{~b}$ & $0.079 \pm 0.01 \mathrm{~A} \mathrm{~b}$ & $0.131 \pm 0.05 \mathrm{~A} \mathrm{ab}$ & $0.108 \pm 0.01 \mathrm{~A} \mathrm{a}$ & $0.062 \pm 0.02 \mathrm{~B} \mathrm{ab}$ & $0.043 \pm 0.0 \mathrm{q} \mathrm{B} \mathrm{b}$ \\
\hline
\end{tabular}

Significiant effects; Ptreatment: 0.392 Pstorege: 0.002 Ptreatment $\times$ Pstorege: 0.050 Ptreatment: 0.130 Pstorege: 0.001 Ptreatment $\times$ Pstorege: 0.001 Significiant effects; Pcv: 0.001 Pcv $\times$ Ptreatment: 0.835 Pcv $\times$ Pstorage: 0.001 Pcv $\times$ Ptreatment $\times$ Pstorage: 0.052

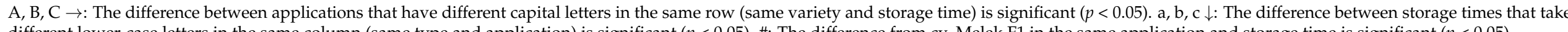
different lower-case letters in the same column (same type and application) is significant $(p<0.05)$. \#: The difference from cv. Melek F1 in the same application and storage time is significant $(p<0.05)$.
} 
The general trend for the respiration rate of cv. Akra F1 was an increase up to the 14th day of storage, and then some fluctuations have been seen, with the final value at the 28th day higher than the default value. For the Melek F1 cultivar there were fluctuations in the respiration rate during storage, with a decreased value at the end of storage. In terms of respiration rate values, the difference between applications was found to be statistically significant, except for the 14th and 24th days of storage, for cv. Akra F1; and 0 and for the 28th day for cv. Melek F1, respectively. The difference among the storage days of cv. Akra F1 compared with cv. Melek F1 were found to be statistically significant for all applications, except for the 28th day with the application of 50 ppm cytokinin, and for the 24th day with the application of 100 ppm cytokinin (Table 2). Respiratory rate results are similar with those of the studies performed by Çavuşoğlu [27] for cauliflower and Costa et al. [42] for broccoli, in which different doses of cytokinin were applied before harvest. Koide and Shi [43] reported that the respiration rate of green peppers increased during storage.

There is an aim to reduce weight loss, respiration rate and ethylene production in products, prevent blackening, delay maturation and softening, and prevent pathogens and physiological disorders by providing low $\mathrm{O}_{2}$ and high $\mathrm{CO}_{2}$ in the environment with MAP applications to fruits and vegetables [44-46]. In cases where there is no correlation between the respiratory rate of the product in the MAP and the permeability of the packaging, anaerobic respiration and ethyl alcohol accumulation occur in parallel with the increase in the amount of $\mathrm{CO}_{2}$ in the environment [47]. It is a situation that negatively affects the quality of the products, leading to the loss of taste and to deterioration. The respiration rate in fresh fruits and vegetables is often seen as a good criterion for determining the storage life of the product [17].

\subsection{Exogenous Amount of Ethylene}

Ethylene is one of the few plant growth regulators that affect growth and development processes, including maturation and aging [48]. Therefore, the prevention of ethylene biosynthesis, or its effect, can play an important role in delaying aging.

In our study, fluctuations in the amount of exogenous ethylene, manifesting decreases and increases during storage, occurred for both pepper cultivars (Table 2). For cv. Akra F1 there were higher exogenous ethylene amounts at the end of storage for both cytokinin applications, and the highest value was after $100 \mathrm{ppm}$ addition. Fluctuations of the exogenous ethylene amount were observed during the storage for cv. Melek F1. Statistical significance, in terms of cytokinin applications, was found for fresh peppers of cv. Akra F1, and for the 0th, 14th and 28th days of storage of cv. Melek F1. The difference among the storage days of cv. Akra F1 compared with cv. Melek F1 on the 0th and 14th days with the application of $50 \mathrm{ppm}$ cytokinin, and on the 7th day of storage after the application of 100 ppm cytokinin, were found to be statistically significant (Table 2). In the present study, the application of cytokinin generally increased ethylene production, as seen in the amount of exogenous ethylene. Exogenous ethylene results are similar with those of the studies using different doses of cytokinin before harvest, performed by Çavuşoğlu [27] for cauliflower and Costa et al. [42] for broccoli.

\subsection{In-Package Gas Composition}

In pepper cultivars, there has been a decrease in the oxygen $\left(\mathrm{O}_{2}\right)$ value and an increase of carbon dioxide $\left(\mathrm{CO}_{2}\right)$ for the in-package gas components during storage. At the end of storage, we found the lowest oxygen level and the highest carbon dioxide value after the application of 50 ppm cytokinin for cv. Akra F1, and after the application of $100 \mathrm{ppm}$ cytokinin for cv. Melek F1, respectively (Table 3). Therefore, a decrease in oxygen and an increase in carbon dioxide during storage after cytokinin applications in both pepper cultivars in MAP had positive effects on the products in MAP by reducing the amount of $\mathrm{O}_{2}$ in the package and increasing the $\mathrm{CO}_{2}$ amount. When the changes in the oxygen and carbon dioxide values were statistically examined, the difference between the applications was found to be significant. 


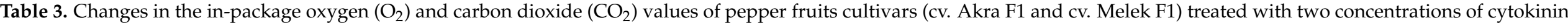
during storage.

\begin{tabular}{|c|c|c|c|c|c|c|c|}
\hline & \multirow[b]{2}{*}{$\begin{array}{l}\text { Storage } \\
\text { Period (Day) }\end{array}$} & \multicolumn{3}{|c|}{ Akra F1 } & \multicolumn{3}{|c|}{ Melek F1 } \\
\hline & & Control & $50 \mathrm{ppm}$ & 100 ppm & Control & 50 ppm & 100 ppm \\
\hline \multirow{5}{*}{$\% \mathrm{O}_{2}$} & 0 & $20.90 \pm 0.00 \mathrm{~A} \mathrm{a}$ & $20.90 \pm 0.00 \mathrm{~A} \mathrm{a}$ & $20.90 \pm 0.00 \mathrm{~A} \mathrm{a}$ & $20.90 \pm 0.00 \mathrm{~A} \mathrm{a}$ & $20.90 \pm 0.00 \mathrm{~A} \mathrm{a}$ & $20.90 \pm 0.00 \mathrm{~A} \mathrm{a}$ \\
\hline & 7 & $19.60 \pm 0.06 \mathrm{~A} \mathrm{bc} \#$ & $17.80 \pm 0.32 \mathrm{~B} \mathrm{bc}$ & $17.80 \pm 0.77 \mathrm{~B} \mathrm{bc}$ & $18.13 \pm 0.23 \mathrm{AB} b c$ & $18.70 \pm 0.20 \mathrm{~A} \mathrm{~b}$ & $17.80 \pm 0.10 \mathrm{~B} \mathrm{bc}$ \\
\hline & 14 & $19.00 \pm 0.15 \mathrm{~A} \mathrm{c}$ & $17.26 \pm 0.41 \mathrm{~B} \mathrm{c}$ & $16.46 \pm 0.42 \mathrm{~B} \mathrm{c} \#$ & $17.60 \pm 0.60 \mathrm{~A} \mathrm{C}$ & $18.23 \pm 0.18 \mathrm{~A} \mathrm{~b}$ & $18.13 \pm 0.18 \mathrm{~A} \mathrm{~b}$ \\
\hline & 24 & $19.66 \pm 0.35 \mathrm{~A} \mathrm{bc} \#$ & $18.46 \pm 0.29 \mathrm{~A} \mathrm{~b}$ & $16.53 \pm 0.49 \mathrm{~B} \mathrm{C}$ & $18.16 \pm 0.18 \mathrm{~A} \mathrm{bc}$ & $19.20 \pm 0.86 \mathrm{~A} \mathrm{~b}$ & $17.60 \pm 0.15 \mathrm{~A} \mathrm{c}$ \\
\hline & 28 & $20.16 \pm 0.37 \mathrm{~A} a b \#$ & $18.33 \pm 0.29 \mathrm{~A} \mathrm{~b}$ & $18.90 \pm 1.00 \mathrm{~A} \mathrm{ab}$ & $18.80 \pm 0.11 \mathrm{~A} \mathrm{~b}$ & $18.60 \pm 0.06 \mathrm{AB} \mathrm{b}$ & $18.10 \pm 0.23 \mathrm{~B} \mathrm{bc}$ \\
\hline \multirow{2}{*}{\multicolumn{8}{|c|}{$\begin{array}{r}\text { Significiant effects; Ptreatment: 0.001 Pstorege: } 0.001 \text { Ptreatment } \times \text { Pstorege: } 0.022 \text { Ptreatment: } 0.011 \text { Pstorege: } 0.001 \text { Ptreatment } \times \text { Pstorege: } 0.155 \\
\text { Significiant effects; Pcv: } 0.649 \text { Pcv } \times \text { Ptreatment: } 0.001 \text { Pcv } \times \text { Pstorage: } 0.184 \text { Pcv } \times \text { Ptreatment } \times \text { Pstorage: } 0.066\end{array}$}} \\
\hline & & & & & & & \\
\hline \multirow{5}{*}{$\% \mathrm{CO}_{2}$} & 0 & $0.30 \pm 0.00 \mathrm{~A} \mathrm{~d}$ & $0.30 \pm 0.00 \mathrm{~A} \mathrm{~d}$ & $0.30 \pm 0.00 \mathrm{~A} \mathrm{c}$ & $0.30 \pm 0.00 \mathrm{~A} \mathrm{~b}$ & $0.30 \pm 0.00 \mathrm{~A} \mathrm{c}$ & $0.30 \pm 0.00 \mathrm{~A} \mathrm{c}$ \\
\hline & 7 & $0.80 \pm 0.00 \mathrm{~B} \mathrm{~b} \#$ & $1.20 \pm 0.06 \mathrm{~A} \mathrm{~b} \#$ & $1.26 \pm 0.08 \mathrm{~A} \mathrm{ab}$ & $1.10 \pm 0.06 \mathrm{AB} a$ & $0.96 \pm 0.03 \mathrm{~B} \mathrm{a}$ & $1.16 \pm 0.07 \mathrm{~A} \mathrm{a}$ \\
\hline & 14 & $0.93 \pm 0.07 \mathrm{~B} \mathrm{a}$ & $1.40 \pm 0.06 \mathrm{~A} \mathrm{a} \mathrm{\#}$ & $1.50 \pm 0.00 \mathrm{~A} \mathrm{a} \mathrm{\#}$ & $1.23 \pm 0.14 \mathrm{~A} \mathrm{a}$ & $1.10 \pm 0.06 \mathrm{~A} \mathrm{a}$ & $1.23 \pm 0.08 \mathrm{~A} \mathrm{a}$ \\
\hline & 24 & $0.60 \pm 0.00 \mathrm{~B} \mathrm{c} \#$ & $0.86 \pm 0.08 \mathrm{~B} \mathrm{C}$ & $1.40 \pm 0.20 \mathrm{~A} \mathrm{a}$ & $0.93 \pm 0.08 \mathrm{~A} \mathrm{a}$ & $0.63 \pm 0.12 \mathrm{~B} \mathrm{~b}$ & $0.96 \pm 0.03 \mathrm{~A} \mathrm{~b}$ \\
\hline & 28 & $0.73 \pm 0.03 \mathrm{~A} \mathrm{~b}$ & $1.03 \pm 0.03 \mathrm{~A} \mathrm{bc} \#$ & $0.93 \pm 0.22 \mathrm{~A} \mathrm{~b}$ & $0.93 \pm 0.08 \mathrm{~A} \mathrm{a}$ & $0.90 \pm 0.00 \mathrm{~A} \mathrm{a}$ & $1.10 \pm 0.06 \mathrm{~A} \mathrm{ab}$ \\
\hline
\end{tabular}

Significiant effects; Ptreatment: 0.001 Pstorege: 0.001 Ptreatment $\times$ Pstorege: 0.003 Ptreatment: 0.002 Pstorege: 0.001 Ptreatment $\times$ Pstorege: 0.393

Significiant effects; Pcv: 0.369 Pcv $\times$ Ptreatment: 0.001 Pcv $\times$ Pstorage: 0.275 Pcv $\times$ Ptreatment $x$ Pstorage: 0.015

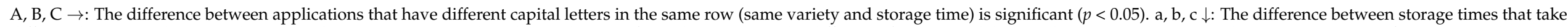
different lower-case letters in the same column (same type and application) is significant $(p<0.05)$. \#: The difference from cv. Melek F1 in the same application and storage time is significant $(p<0.05)$. 


\subsection{Antioxidative Enzyme (SOD, CAT and APX) Assays}

Antioxidants and phenolics in plants help effectively protect them from the oxidative damage caused by free radicals and reactive oxygen species by interacting with them and stabilizing free radicals $[49,50]$. The accumulation of reactive oxygen species results from the change in the balance between the production of reactive oxygen species and their elimination process, and it decreases the storage quality and marketability of vegetables [51,52]. The main scavengers for reactive oxygen species include antioxidant enzymes such as CAT, SOD, APX, GR and POX [53], as well as antioxidant compounds such as carotenoids, ascorbate, glutathione, etc. [54]. While SOD catalyzes the separation of the superoxide anion into $\mathrm{H}_{2} \mathrm{O}_{2}$ and $\mathrm{O}_{2}$, CAT and APX are reported to play a role in the elimination of $\mathrm{H}_{2} \mathrm{O}_{2}$ from plant cells [55].

An increase in antioxidative enzymes (SOD, CAT and APX) was observed, comparing the beginning and the end of storage, for both pepper cultivars, with some fluctuations occurring during storage.

It was seen that the activity of the SOD enzyme increased in nearly all storage times. Higher SOD values were found for the Melek F1 pepper cultivar and for peppers after a $100 \mathrm{ppm}$ cytokinin application. As for the SOD activity, in terms of the difference between applications, the 28th day of storage was found to be statistically significant in cv. Akra F1, while the difference between applications was not statistically significant in cv. Melek F1. The difference among the storage days of cv. Akra F1 compared with cv. Melek F1 on the 28th day with the application of $50 \mathrm{ppm}$ cytokinin was found to be statistically significant (Table 4).

Some fluctuations in the activity of the CAT enzyme were observed. There were increases and decreases according to the applications and the day of storage. The growth was observed up to the 24th day, and then the values slightly decreased. At the end of storage, the highest CAT values were observed after a 50 ppm cytokinin application for both cultivars. While there was no statistically significant difference in the activity of the CAT enzyme among the applications in cv. Akra F1, the results for the 7th and 14th days of storage were statistically significant in cv. Melek F1. The difference among the storage days of cv. Akra F1 compared with cv. Melek F1 on the 14th, 24th and 28th days after the application of $100 \mathrm{ppm}$ cytokinin was found to be significantly different (Table 4).

It was determined that the activity of the APX enzyme increased up to the 14th day for cv. Akra F1 and decreased afterwards, with higher values in the end for peppers with cytokinin application compared to fresh peppers after the harvest. Regular increases were observed for cv. Melek F1 during the storage periods. At the end of storage, it was determined that the highest APX values were found for cv. Melek F1, and for both cultivars after a $100 \mathrm{ppm}$ cytokinin application. In terms of APX values, there were significant differences among the applications of both cultivars after all storage days, except for the fresh products (Table 4).

Considering the data examined in the present study, it was found that the SOD, CAT and APX values of both pepper cultivars were higher than those of the control cytokinin application. The results of SOD, CAT and APX are analogous to the results of Zhang et al. [56], who applied 6-benzylaminopurine (BAP) to litchi fruits. 
Table 4. Changes in SOD, CAT, APX and MDA values of pepper fruits cultivars (cv. Akra F1 and cv. Melek F1) treated with two concentrations of cytokinin during storage.

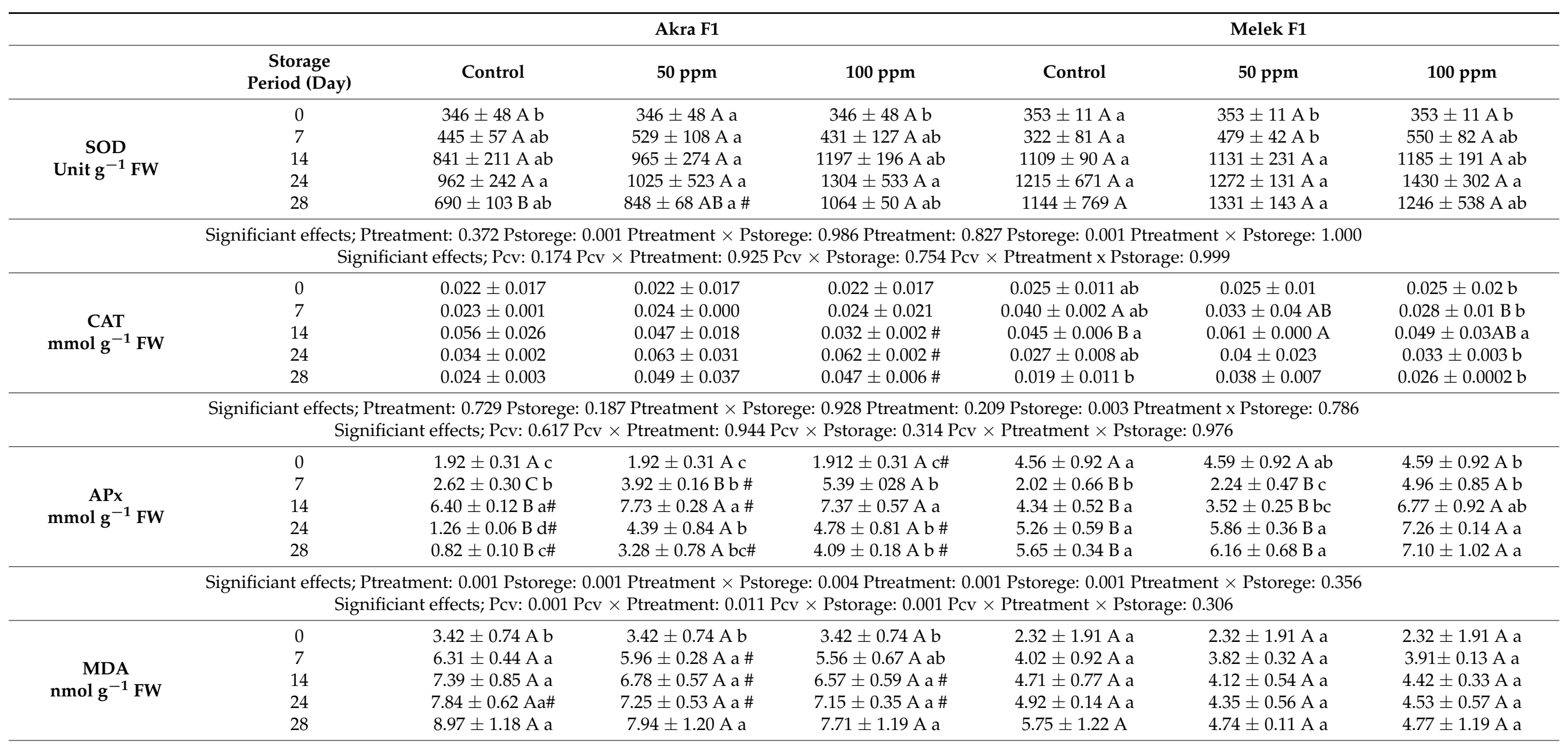

Significiant effects; Ptreatment: 0.338 Pstorege: 0.001 Ptreatment $\times$ Pstorege: 0.999 Ptreatment: 0.761 Pstorege: 0.031 Ptreatment $\times$ Pstorege: 1.000 Significiant effects; Pcv: 0.001 Pcv $\times$ Ptreatment: 0.899 Pcv $\times$ Pstorage: 0.367 Pcv $\times$ Ptreatment $x$ Pstorage: 1.000

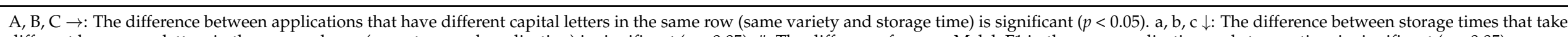
different lower-case letters in the same column (same type and application) is significant $(p<0.05)$. \#: The difference from cv. Melek F1 in the same application and storage time is significant $(p<0.05)$. 


\subsection{Lipid Peroxidation}

Conditions of aging and stress in plants, in different parts of the cells, increase the formation of reactive oxygen species (ROS), including superoxide radicals $\left(\mathrm{O}_{2}{ }^{-}\right)$, hydrogen peroxide $\left(\mathrm{H}_{2} \mathrm{O}_{2}\right)$ and hydroxyl radicals $\left(\mathrm{OH}^{-}\right)[57,58]$. In other words, it can be said that cytokinin contributes to the delay of the accumulation of reactive oxygen species in peppers fruits. The loss of membrane integrity causes the decomposition of enzymes and substrates, which initiates enzymatic blackening [59]. Membrane damage in plants is associated with lipid peroxidation caused by reactive oxygen species [60], while malondialdehyde (MDA) is a product of lipid peroxidation.

Regular increases of MDA values were observed for both pepper cultivars during storage. According to the results of the analyses, the highest MDA values were at the end of storage, with similar values for the products after application, and with higher values for the Akra F1 cultivar. The difference among cytokinin applications in cv. Akra F1 and cv. Melek F1 was not statistically significant. The differences among the storage days of cv. Akra F1 compared with cv. Melek F1 were on the 7th, 14th and 24th days after storage with a pre-harvest $50 \mathrm{ppm}$ cytokinin application; and on the 14th and 24th days after a $100 \mathrm{ppm}$ application (Table 4). It was observed that the samples treated with cytokinin in cv. Akra F1 and cv. Melek F1 showed a lower lipid peroxidation compared to the control. The results of MDA are in line with those of Zhang et al. [56], who applied 6-benzylaminopurine to litchi fruits.

\subsection{Total Phenolic Content and Total Antioxidant Activity}

Phenolic compounds are present in many types of fruits and vegetables, often in a large amount, and represent a wide range of chemical compounds. They are secondary metabolites that are effective in important functions in the plant's life cycle, act as antioxidants with free radical scavenging properties and have the ability to catalyze lipid peroxidation [61]. The content of phenolic compounds varies depending on the species, cultivar and environmental conditions [62-64].

The total phenolic content (TP) of both pepper cultivars had fluctuations throughout the storage, with a final increase at the end of storage. The higher phenolic content after the storage was determined for $\mathrm{cv}$. Akra F1, and for a $50 \mathrm{ppm}$ cytokinin application in both cultivars. These increases are thought to be due to the inhibition of catalase activity, which enables the synthesis of phenolic compounds and the stimulation of the phenylalanine lyase gene $[65,66]$. Plant antioxidants, including anthocyanins and phenolic substances, occur naturally in plants. Free radicals provide beneficial effects in fruits and vegetables [67].

Moreover, the total antioxidant activity (AA) increased at the end of storage in comparison to that of fresh products, with fluctuations during storage for both pepper cultivars. At the end of storage, higher AA values were found for cv. Akra F1, and for a $50 \mathrm{ppm}$ cytokinin application in both pepper cultivars.

As for the total antioxidant activity, the storage periods, except for the 0th day, were significant for cv. Akra F1, while the results for storage periods in the 7th and 28th days were only significant for cv. Melek F1. The difference among the storage days of cv. Akra F1 compared with cv. Melek F1 on the 14th and 28th days with the application of $50 \mathrm{ppm}$ cytokine were found to be statistically significant (Table 5). The difference between the applications in the 7th, 24th and 28th storage days of cv. Akra F1 and the 7th, 14th and 28th days in cv. Melek F1 was statistically significant. 


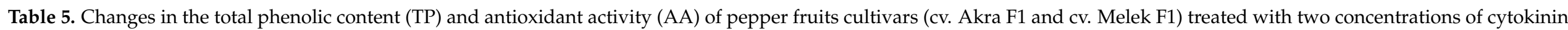
during storage.

\begin{tabular}{|c|c|c|c|c|c|c|c|}
\hline & \multirow[b]{2}{*}{$\begin{array}{c}\text { Storage } \\
\text { Period (Day) }\end{array}$} & \multicolumn{3}{|c|}{ Akra F1 } & \multicolumn{3}{|c|}{ Melek F1 } \\
\hline & & Control & $50 \mathrm{ppm}$ & 100 ppm & Control & 50 ppm & 100 ppm \\
\hline \multirow{5}{*}{$\begin{array}{c}\text { TP } \\
\text { mg GAE/100 g }\end{array}$} & 0 & $14.351 \pm 4.86 \mathrm{~A} \mathrm{~b}$ & $14.351 \pm 4.86 \mathrm{~A} \mathrm{C}$ & $14.351 \pm 4.86 \mathrm{~A} \mathrm{~b}$ & $19.25 \pm 3.72 \mathrm{~A} \mathrm{c}$ & $19.259 \pm 3.72 \mathrm{~A} \mathrm{~b}$ & $19.259 \pm 3.72 \mathrm{~A} \mathrm{~b}$ \\
\hline & 7 & $5.890 \pm 1.72 \mathrm{~A} \mathrm{~b} \mathrm{\#}$ & $29.593 \pm 3.14 \mathrm{Ab}$ & $6.63 \pm 3.14 \mathrm{~B} \mathrm{~b}$ & $35.07 \pm 7.70 \mathrm{AB} \mathrm{ab}$ & $46.607 \pm 7.88 \mathrm{~A} \mathrm{a}$ & $13.919 \pm 6.93 \mathrm{~B} \mathrm{~b}$ \\
\hline & 14 & $13.111 \pm 4.08 \mathrm{~A} \mathrm{~b}$ & $7.82 \pm 2.02$ B c \# & $13.05 \pm 3.14 \mathrm{~A} \mathrm{~b}$ & $26.573 \pm 4.48 \mathrm{~A} \mathrm{C}$ & $33.057 \pm 2.88 \mathrm{~A} \mathrm{ab}$ & $21.012 \pm 3.66 \mathrm{~A} \mathrm{~b}$ \\
\hline & 24 & $61.730 \pm 1.27 \mathrm{~A} \mathrm{a} \mathrm{\#}$ & $51.634 \pm 1.27 \mathrm{~B} \mathrm{a}$ & $49.627 \pm 3.10 \mathrm{~B} \mathrm{a}$ & $48.476 \pm 1.19 \mathrm{~A} \mathrm{a}$ & $42.509 \pm 4.28 \mathrm{~A} \mathrm{a}$ & $46.034 \pm 1.49 \mathrm{~A} \mathrm{a}$ \\
\hline & 28 & $60.649 \pm 2.07 \mathrm{~A} \mathrm{a} \mathrm{\#}$ & $57.868 \pm 0.78$ Aa\# & $46.952 \pm 2.15 \mathrm{~B} \mathrm{a}$ & $39.454 \pm 1.73 \mathrm{AB} \mathrm{ab}$ & $47.064 \pm 2.42 \mathrm{~A} \mathrm{a}$ & $38.300 \pm 2.64 \mathrm{~B} \mathrm{a}$ \\
\hline \multirow{5}{*}{$\underset{\mu \mathrm{mol} \mathrm{TE} / \mathrm{g}}{\text { AA }}$} & 0 & $5.724 \pm 0.39 \mathrm{~A} \mathrm{c}$ & $5.724 \pm 0.39 \mathrm{~A} \mathrm{~b}$ & $5.724 \pm 0.39 \mathrm{~A} \mathrm{~b}$ & $5.192 \pm 0.76 \mathrm{~A} \mathrm{~b}$ & $5.192 \pm 0.76 \mathrm{~A} \mathrm{~b}$ & $5.192 \pm 0.76 \mathrm{~A} \mathrm{~b}$ \\
\hline & 7 & $2.535 \pm 0.63 \mathrm{~B} \mathrm{~d} \#$ & $8.294 \pm 1.09 \mathrm{~A} \mathrm{~b}$ & $2.558 \pm 0.46 \mathrm{~B} \mathrm{c}$ & $11.72 \pm 3.19 \mathrm{AB}$ a & $15.468 \pm 3.26 \mathrm{~A} \mathrm{a}$ & $4.868 \pm 1.35 \mathrm{~B} \mathrm{~b}$ \\
\hline & 14 & $3.757 \pm 0.74 \mathrm{~A} \mathrm{~d}$ & $2.781 \pm 0.85$ Ac \# & $3.369 \pm 1.19 \mathrm{~A} \mathrm{C}$ & $7.751 \pm 1.32 \mathrm{AB} a b$ & $8.713 \pm 0.78 \mathrm{~A} \mathrm{~b}$ & $4.917 \pm 0.99 \mathrm{~B} \mathrm{~b}$ \\
\hline & 24 & $18.919 \pm 0.28 \mathrm{~A} \mathrm{a} \mathrm{\#}$ & $12.908 \pm 1.08 \mathrm{~B} \mathrm{a}$ & $11.841 \pm 0.75 \mathrm{~B} \mathrm{a}$ & $11.407 \pm 0.53 \mathrm{~A} \mathrm{a}$ & $9.708 \pm 1.38 \mathrm{~A} \mathrm{~b}$ & $11.474 \pm 0.27 \mathrm{~A} \mathrm{a}$ \\
\hline & 28 & $15.045 \pm 0.52 \mathrm{~A} \mathrm{b \#}$ & $14.163 \pm 0.39$ Aa\# & $10.332 \pm 0.40 \mathrm{Ba} \#$ & $7.796 \pm 0.30 \mathrm{~B} \mathrm{ab}$ & $9.647 \pm 0.66 \mathrm{~A} \mathrm{~b}$ & $6.903 \pm 0.45 \mathrm{~B} \mathrm{~b}$ \\
\hline
\end{tabular}

Significiant effects; Ptreatment: 0.001 Pstorege: 0.001 Ptreatment $\times$ Pstorege: 0.001 Ptreatment: 0.006 Pstorege: 0.001 Ptreatment $\times$ Pstorege: 0.018

Significiant effects; Pcv: 0.713 Pcv $\times$ Ptreatment: 0.359 Pcv $\times$ Pstorage: 0.001 Pcv $\times$ Ptreatment $\times$ Pstorage: 0.006

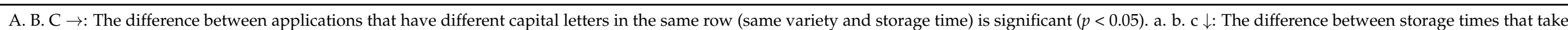
different lower-case letters in the same column (same type and application) is significant $(p<0.05)$. \#: The difference from cv. Melek F1 in the same application and storage time is significant $(p<0.05)$. 
In the present study, it was determined that pre-harvest cytokinin application increased antioxidant substances during storage. In terms of changes in total phenolic content and total antioxidant activity, our results (Table 5) were similar to those of PerezAmbrocio et al. $[68,69]$, who studied different irradiations in pepper.

\subsection{Correlations between Traits}

In the study, a correlation analysis was performed to determine the relationships between measured parameters in cv. Akra F1 and Melek F1 during storage (Tables 6 and 7). In cv. Akra 1, the highest positive correlation values were obtained from TP and AA $\left(\mathrm{r}=0.961^{* *}\right)$, while the lowest relationships were observed between $\mathrm{O}_{2}$ and $\mathrm{CO}_{2}(\mathrm{r}=-0.952)$. For cultivar Melek F1, the highest positive correlation values were obtained from $\mathrm{b}$ and $\mathrm{C}$ $\left(r=0.996^{* *}\right)$, while the lowest relationships were observed between $a$ and $C(r=-0.926)$. 
Table 6. Pearson's correlation coefficients between measured parameters of cv. Akra F1 during storage.

\begin{tabular}{|c|c|c|c|c|c|c|c|c|c|c|c|c|c|c|c|}
\hline & $L^{*}$ & $a^{*}$ & $b^{*}$ & $C^{*}$ & hue & TP & AA & $\mathrm{O}_{2}$ & $\mathrm{CO}_{2}$ & RR & EA & SOD & CAT & APX & MDA \\
\hline$L^{*}$ & 1 & & & & & & & & & & & & & & \\
\hline$a^{*}$ & $-0.637^{* *}$ & 1 & & & & & & & & & & & & & \\
\hline$b^{*}$ & $0.807^{* *}$ & -0.292 & 1 & & & & & & & & & & & & \\
\hline$C^{*}$ & $0.455^{* *}$ & -0.244 & $0.467^{* *}$ & 1 & & & & & & & & & & & \\
\hline hue & -0.192 & $-0.525^{* *}$ & $-0.640^{* *}$ & -0.217 & 1 & & & & & & & & & & \\
\hline $\mathrm{TP}$ & -0.154 & $0.493^{* *}$ & 0.134 & -0.075 & $-0.484^{* *}$ & 1 & & & & & & & & & \\
\hline AA & -0.097 & $0.432 * *$ & 0.152 & -0.015 & $-0.453^{* *}$ & $0.961^{* *}$ & 1 & & & & & & & & \\
\hline $\mathrm{O}_{2}$ & $0.496^{* *}$ & $-0.386^{* *}$ & $0.386^{* *}$ & 0.264 & -0.016 & -0.039 & 0.082 & 1 & & & & & & & \\
\hline RR & 0.172 & 0.128 & $0.396^{* *}$ & 0.259 & $-0.446^{* *}$ & 0.009 & -0.005 & $-0.294 *$ & $0.357^{*}$ & 1 & & & & & \\
\hline EA & 0.051 & 0.101 & 0.053 & 0.085 & -0.172 & -0.161 & -0.227 & -0.223 & 0.296 * & $0.548^{* *}$ & 1 & & & & \\
\hline SOD & -0.209 & $0.473^{* *}$ & -0.078 & -0.179 & -0.280 & $0.366^{*}$ & 0.246 & $-0.485^{* *}$ & $0.441^{* *}$ & 0.239 & 0.191 & 1 & & & \\
\hline CAT & -0.152 & 0.272 & -0.023 & -0.108 & -0.213 & 0.241 & 0.142 & -0.189 & 0.180 & 0.139 & 0.291 & $0.382^{* *}$ & 1 & & \\
\hline APX & -0.201 & 0.112 & -0.254 & -0.125 & 0.104 & $-0.368 *$ & $-0.489^{* *}$ & $-0.700^{* *}$ & $0.708^{* *}$ & $0.399 * *$ & $0.493^{* *}$ & 0.348 * & $0.336^{*}$ & 1 & \\
\hline MDA & -0.115 & $0.559^{* *}$ & 0.246 & -0.085 & $-0.632^{* *}$ & $0.586^{* *}$ & $0.448^{* *}$ & $-0.319 *$ & $0.351 *$ & $0.451^{* *}$ & 0.206 & $0.486^{* *}$ & 0.279 & 0.147 & 1 \\
\hline
\end{tabular}

*: Correlation is significant at $p<0.05$. **: Correlation is significant at $p<0.01$. WL: Weight loss, EA: Ethylene amount, RR: Respiration rate, TP: Total phenolic content, AA: Antioxidant activity. 
Table 7. Pearson's correlation coefficients between measured parameters of cv. Melek F1 during storage.

\begin{tabular}{|c|c|c|c|c|c|c|c|c|c|c|c|c|c|c|c|}
\hline & $L^{*}$ & $a^{*}$ & $b^{*}$ & $C^{*}$ & hue & TP & AA & $\mathrm{O}_{2}$ & $\mathrm{CO}_{2}$ & RR & EA & SOD & CAT & APX & MDA \\
\hline$L^{*}$ & 1 & & & & & & & & & & & & & & \\
\hline$a^{*}$ & 0.148 & 1 & & & & & & & & & & & & & \\
\hline$b^{*}$ & 0.048 & $-0.891^{* *}$ & 1 & & & & & & & & & & & & \\
\hline$C^{*}$ & 0.011 & $-0.926^{* *}$ & $0.996^{* *}$ & 1 & & & & & & & & & & & \\
\hline hue & $-0.352 *$ & $-0.736^{* *}$ & 0.351 * & $0.427^{* *}$ & 1 & & & & & & & & & & \\
\hline $\mathrm{TP}$ & 0.040 & $0.428^{* *}$ & -0.221 & -0.264 & $-0.555^{* *}$ & 1 & & & & & & & & & \\
\hline $\mathrm{AA}$ & $-0.355^{*}$ & 0.230 & -0.158 & -0.173 & -0.269 & $0.791 * *$ & 1 & & & & & & & & \\
\hline $\mathrm{O}_{2}$ & 0.125 & $-0.529^{* *}$ & $0.603^{* *}$ & $0.601^{* *}$ & 0.180 & $-0.344 *$ & $-0.309 *$ & 1 & & & & & & & \\
\hline RR & 0.011 & $-0.515^{* *}$ & $0.548^{* *}$ & $0.551^{* *}$ & 0.271 & $-0.423^{* *}$ & $-0.393^{* *}$ & $0.437^{* *}$ & $-0.385^{* *}$ & 1 & & & & & \\
\hline EA & -0.005 & -0.227 & 0.206 & 0.214 & 0.150 & -0.061 & 0.061 & 0.002 & 0.025 & 0.060 & 1 & & & & \\
\hline SOD & 0.000 & 0.359 * & -0.226 & -0.255 & $-0.388^{* *}$ & $0.337^{*}$ & 0.113 & $-0.375^{*}$ & 0.273 & -0.078 & -0.254 & 1 & & & \\
\hline CAT & -0.140 & 0.097 & -0.129 & -0.127 & 0.008 & 0.101 & 0.156 & $-0.424^{* *}$ & $0.406^{* *}$ & 0.177 & -0.247 & 0.168 & 1 & & \\
\hline APX & 0.203 & 0.215 & -0.094 & -0.118 & -0.281 & 0.063 & -0.233 & -0.121 & 0.039 & -0.067 & $-0.317^{*}$ & 0.351 * & 0.021 & 1 & \\
\hline MDA & -0.083 & 0.379 * & $-0.374 *$ & $-0.383^{* *}$ & -0.233 & 0.211 & 0.111 & $-0.469^{* *}$ & $0.450 * *$ & $-0.343 *$ & -0.139 & 0.257 & 0.246 & $0.296^{*}$ & 1 \\
\hline
\end{tabular}

*: Correlation is significant at $p<0.05 .{ }^{* *}$ : Correlation is significant at $p<0.01$. WL: Weight loss, EA: Ethylene amount, RR: Respiration rate, TP: Total phenolic content, AA: Antioxidant activity. 


\section{Conclusions}

The effects of two doses of cytokinin (50 and $100 \mathrm{ppm}$ ) in a pre-harvest application, by spraying, on the post-harvest physiology of Akra F1 and Melek F1 pepper cultivars (Capsicum annuиm L.) were investigated. It was observed that cytokinin can delay aging in peppers of both cultivars stored for 28 days. These applications have positive effects on the in-package gas composition, antioxidative enzymes (SOD, CAT and APX), lipid peroxidation (MDA), total phenolics and total antioxidant activity of peppers. The application of up to $100 \mathrm{ppm}$ cytokinin might be suitable for use in pepper cultivars cv. Akra F1 and Melek $\mathrm{F} 1$, in terms of their in-package gas composition $\left(\mathrm{O}_{2}\right.$ and $\left.\mathrm{CO}_{2}\right)$, antioxidative enzymes, lipid peroxidation, total phenolic content and antioxidant activity. A high positive correlation was found between the total phenolic content and antioxidant activity, SOD and APX and ethylene amount and respiration rate.

Author Contributions: Conceptualization, S.C. and S.S. (Suat Sensoy); data curation, A.K. and O.T; formal analysis, S.C., F.I. and N.Y.; methodology, S.C. and A.K.; project administration, S.C. and S.S. (Suat Sensoy); visualization, S.E.; J.M.; S.K. and A.K.; writing-original draft, S.C., S.E., S.S. (Sona Skrovankova), J.M. and A.K.; writing-review and editing, S.C., S.S. (Suat Sensoy), S.E., A.A., J.M. and O.T. All authors have read and agreed to the published version of the manuscript.

Funding: This work was supported by the internal grant of TBU in Zlin (No. IGA/FT/2021/008).

Institutional Review Board Statement: Not applicable.

Informed Consent Statement: Not applicable.

Data Availability Statement: New research data were presented in this contribution.

Acknowledgments: This study was carried out in Van Yuzuncu Yil University's Advanced Technology Research and Application Center.

Conflicts of Interest: The authors declare that they have no conflict of interest.

\section{References}

1. Trujillo, J.P.F.; Serrano, J.; Martínez, J. Quality of Red Sweet Pepper Fruit Treated with 1-MCP during a Simulated Post-harvest Handling Chain. Food Sci. Technol. Int. 2009, 15, 23-30. [CrossRef]

2. Ozturk, I.; Ercisli, S.; Kalkan, F.; Demir, B. Some chemical and physico-mechanical properties of pear cultivars. Afr. J. Biotechnol. 2009, 8, 687-693.

3. Bat, H.; Shidfar, M.; Comlekcioglu, N.; Ellialtioglu, S.S. In vitro and rogenesis in pepper and the affecting factors on success: I. Carbon source and concentrations. Biotech Studies 2020, 29, 62-68. [CrossRef]

4. Dogan, H.; Ercisli, S.; Jurikova, T.; Temim, E.; Leto, A.; Hadziabulic, A.; Tosun, M.; Narmanlioglu, H.K.; Zia-Ul-Haq, M. Physicochemical and antioxidant characteristics of fruits of cape gooseberry (Physalis peruviana L.) from Turkey. Oxid. Commun. 2014, 37, 1005-1014.

5. Karataş, N.; Şengül, M. Some important physicochemical and bioactive characteristics of the main apricot cultivars from Turkey. Turk. J. Agric. For. 2020, 44, 651-661. [CrossRef]

6. Conforti, F.; Statti, G.A.; Menichini, F. Chemical and biological variability of hot pepper fruits (Capsicum annuum var. acuminatum L.) in relation to maturity stage. Food Chem. 2007, 102, 1096-1104. [CrossRef]

7. Takahashi, M.; Yoshida, C.; Komoda, T. Establishing an efficient fruit ripening method for sweet pepper (Capsicum anuum L.) through light irradiation and dark processing. Hortic. J. 2018, 87, 73-79. [CrossRef]

8. Valenzuela, J.L.; Manzano, S.; Palma, F.; Carvajal, F.; Garrido, D.; Jamilena, M. Oxidative stress associated with chilling injury in immature fruit: Postharvest technological and biotechnological solutions. Int. J. Mol. Sci. 2017, 18, 1467. [CrossRef]

9. Kabir, M.S.N.; Chowdhury, M.; Lee, W.H.; Hwang, Y.S.; Cho, S.I.; Chung, S.O. Influence of delayed cooling on quality of bell pepper (Capsicum annuum L.) stored in a controlled chamber. Emir. J. Food Agric. 2019, 31, 271-280.

10. Mohammed, B.; Abdulsalam, Z.; Ahmed, B. Profitability in chilli pepper production in Kaduna State, Nigeria. Curr. J. Appl. Sci. Technol. 2016, 12, 1-9. [CrossRef]

11. FAOSTAT 2019. Available online: http://www.fao.org/faostat/en/\#data/QC (accessed on 12 April 2020).

12. Jin-Hua, D.; Mao-Run, F.; Miao-Miao, L.; Wei, X. Effects of chlorine dioxide gas on postharvest physiology and storage quality of green bell pepper (Capsicum frutescens L. var. Longrum). Agric. Sci. China 2007, 6, 214-219. [CrossRef]

13. Rao, T.R.; Gol, N.B.; Shah, K.K. Effect of postharvest treatments and storage temperatures on the quality and shelf life of sweet pepper (Capsicum annuum L.). Sci. Hortic. 2011, 132, 18-26. [CrossRef]

14. Risse, R.A.; Miller, W.R. Individual film wrapping of Florida cucumbers, eggplant, peppers and tomatoes for extending shelf life. J. Plast. Film Sheet. 1986, 2, 163-171. [CrossRef] 
15. Lownds, N.K.; Banaras, M.; Bosland, P.W. Postharvest water loss and storage quality of nine pepper (Capsicum) cultivars. HortScience 1994, 29, 191-193. [CrossRef]

16. Polderdijk, J.J.; Boerrigter, H.A.M.; Wilkinson, E.C.; Meijer, J.G.; Janssens, M.F.M. The effects of controlled atmosphere storage at varying levels of relative humidity on weight loss, softening and decay of red bell peppers. Sci. Hortic. 1993, 55, 315-321. [CrossRef]

17. Doğan, A.; Selçuk, N.; Erkan, M. Comparison of pesticide-free and conventional production systems on postharvest quality and nutritional parameters of peppers in different storage conditions. Sci. Hortic. 2016, 207, 104-116. [CrossRef]

18. Raffo, A.; Baiamonte, I.; Nardo, N.; Paoletti, F. Internal quality andantioxidants content of cold-stored red sweet peppers as affected by polyethylene bag packaging and hot water treatment. Eur. Food Res. Technol. 2007, 225, 395-405. [CrossRef]

19. Manolopoulou, H.; Xanthopoulos, G.; Douros, N.; Lambrinos, G. Modified atmosphere packaging storage of green bell peppers: Quality criteria. Biosyst. Eng. 2010, 106, 535-543. [CrossRef]

20. Ercisli, S.; Esitken, A.; Cangi, R.; Sahin, F. Adventitious root formation of kiwifruit in relation to sampling date, IBA and Agrobacterium rubi inoculation. Plant Growth Regul. 2003, 41, 133-137. [CrossRef]

21. Alfosea-Simón, M.; Simón-Grao, S.; Zavala-Gonzalez, E.A.; Cámara-Zapata, J.M.; Simón, I.; Martínez-Nicolás, J.J.; Lidón, V.; Rodríguez-Ortega, W.M.; García-Sánchez, F. Application of biostimulants containing amino acids to tomatoes could favor sustainable cultivation: Implications for Tyrosine, Lysine, and Methionine. Sustainability 2020, 12, 9729. [CrossRef]

22. Mollova, S.; Fidan, H.; Antonova, D.; Bozhilov, D.; Stanev, S.; Kostova, I.; Stoyanova, A. Chemical composition and antimicrobial and antioxidant activity of Helichrysum italicum (Roth) G. Don subspecies essential oils. Turk. J. Agric. For. 2020, 44, 371-378. [CrossRef]

23. Kusvuran, S.; Kaya, E.; Ellialtioğlu, S. Şebnem Role of Grafting in Tolerance to Salt Stress in Melon (Cucumis melo L.) Plants: Ion regulation and antioxidant defense systems. Tarla Bitk. Merk. Arastirma Enst. 2021, 30, 22-32. [CrossRef]

24. Clarke, S.F.; Jameson, P.E.; Downs, C. The influence of 6-benzylaminopurine on post-harvest senescence of floral tissues of broccoli (Brassica oleracea var Italica). Plant Growth Regul. 1994, 14, 21-27. [CrossRef]

25. Al-Qurashi, A.D.; Awad, M.A. Postharvest gibberellic acid, 6-benzylaminopurine and calcium chloride dipping affect quality, antioxidant compounds, radical scavenging capacity and enzymes activities of 'Grand Nain' bananas during shelf life. Sci. Hortic. 2019, 253, 187-194. [CrossRef]

26. Mulagund, J.; Porika, H.; Soorianathasundaram, K.; Deepika, C. Influence of growth regulators combined with chemicals to improve post-harvest fruit quality in banana cv. Nendran (Musa AAB). J. Food Process. Technol. 2015, 6, 1-8.

27. Cavusoglu, S. Hasat Öncesi Sitokinin Uygulamasının Karnabaharların (Brassica oleracea L. botrytis) Hasat Sonrası Fizyolojisine Etkisi. Ph.D. Thesis, Ankara Üniversitesi, Ankara, Turkey, 2008.

28. Jebara, S.; Jebara, M.; Limam, F.; Aouani, M.E. Changes in ascorbate peroxidase, catalase, guaiacol peroxidase and superoxide dismutase activities in common bean (Phaseolus vulgaris) nodules under salt stress. J. Plant Physiol. 2005, 162, 929-936. [CrossRef]

29. Güneri Bağci, E. Nohut Çeşitlerinde Kuraklığa Bağlı Oksidatif Stresin Fizyolojik ve Biyokimyasal Parametrelerle Belirlenmesi. Ph.D. Thesis, Ankara Üniversitesi, Ankara, Turkey, 2010.

30. Swain, T.; Hillis, W.E. The phenolic constituents of Prunus domestica. I. The quantitative analysis of phenolic constituents. J. Sci. Food Agric. 1959, 10, 63-68. [CrossRef]

31. Benzie, I.E.F.; Strain, J.J. The ferric reducing ability of plasma (FRAP) as a measure of "antioxidant power": The FRAP assay. Anal. Biochem. 1996, 239, 70-76. [CrossRef] [PubMed]

32. Casquero, P.A.; Sanz, M.A.; Guerra, M. Effect of storage conditions on sensory properties of Bierzo roasted pepper. J. Sci. Food Agric. 2011, 91, 80-84. [CrossRef]

33. Çavuşoğlu, Ş.; Gökçenay, G. Farklı dozlarda uygulanan sitokininin beyaz şapkalı mantarın (Agaricus bisporus) muhafazası üzerine etkisi. Mantar Dergisi 2018, 9, 80-91.

34. Renquist, A.R.; Reid, J.B. Quality of processing tomato (Lycopersicon esculentum) fruit from four bloom dates in relation to optimal harvest timing. N. Z. J. Crop Hort. Sci. 1998, 26, 161-168. [CrossRef]

35. Tigist, M.; Workneh, T.S.; Woldetsadik, K. Effects of variety on the quality of tomato stored under ambient conditions. J. Food Sci. Technol. 2013, 50, 477-486. [CrossRef]

36. Tsantili, E.; Rekoumi, K.; Roussos, P.A.; Pontikis, C. Effects of postharvest treatment with N6-benzyladenine on green olive fruit. J. Hortic. Sci. Biotechnol. 2002, 77, 294-299. [CrossRef]

37. Rushing, J.W. Cytokinins affect respiration, ethylene production, and chlorophyll retention of packaged broccoli florets. HortScience 1990, 25, 88-90. [CrossRef]

38. Downs, C.G.; Somerfield, S.D.; Davey, M.C. Cytokinin treatment delays senescence but not sucrose loss in harvested broccoli. Postharvest Biol. Techol. 1997, 11, 93-100. [CrossRef]

39. McGuire, R.G. Reporting of objective color measurements. HortScience 1992, 27, 1254-1255. [CrossRef]

40. Tadesse, T.; Hewett, E.W.; Nichols, M.A.; Fisher, K.J. Changes in physicochemical attributes of sweet pepper cv. Domino during fruit growth and development. Sci. Hortic. 2002, 93, 91-103. [CrossRef]

41. Barrera, J.; Hernandez, M.S.; Melgarejo, L.M.; Fernandez-Trujillo, J.P. Physiological changes in Amazonic hot pepper during growth, ripening and storage. Acta Hort. 2005, 682, 2207-2214. [CrossRef]

42. Lee, D.S.; Heggar, P.E.; Lee, J.; Yam, K.L. Model for fresh produce respiration in modified atmospheres based upon the principle of enzyme kinetics. J. Food Sci. 1991, 56, 1580-1585. [CrossRef] 
43. Costa, M.L.; Civello, P.M.; Chaves, A.R.; Martinez, G.A. Effect of ethephon and 6-benzylaminopurine on chlorophyll degrading enzymes and a peroxidase-linked chlorophyll bleaching during postharvest senescence of broccoli (Brassica oleracea L.) at $20{ }^{\circ} \mathrm{C}$. Postharvest Biol. Technol. 2005, 35, 191-199. [CrossRef]

44. Koide, S.; Shi, J. Microbial and quality evaluation of green peppers stored inbiodegradable film packaging. Food Control 2007, 18, 1121-1125. [CrossRef]

45. Kader, A.A.; Zagory, D.; Kerbel, E.L.; Wang, C.Y. Modified atmosphere packaging of fruit and vegetables. Food Sci. Nutr. 1989, 28, 1-30. [CrossRef] [PubMed]

46. Artés, F. Diseno y cálculo de polímeros sintéticos de interes para la conservación hortofrutícola en atmósfera modificada. In Nuevo Curso de Ingeniería Del Frío; Colegio Oficial de Ingenieros Agronómos de Murcia: Murcia, Spain, 1993; pp. 427-454.

47. Toivonen, P.M.; DeEll, J.R. Physiology of fresh-cut fruits and vegetables. In Fresh-Cut Fruits and Vegetables; Madrid, A., Ed.; CRC Press: Boca Raton, FL, USA, 2002; pp. 99-131.

48. Ait-Oubahou, A. Modified atmosphere packaging of tomato fruit. CIHEAM-Options Mediterr. 1999, 42, $103-114$.

49. Saltveit, M.E. Effect of ethylene on quality of fresh fruits and vegetables. Postharvest Biol. Technol. 1999, 15, 279-292. [CrossRef]

50. Hamid, A.A.; Aiyelaagbe, O.O.; Usman, L.A.; Ameen, O.M.; Lawal, A. Antioxidants: Its medicinal and pharmacological applications. Afr. J. Pure Appl. Chem. 2010, 4, 142-151.

51. Serce, S.; Ozgen, M.; Torun, A.A.; Ercisli, S. Chemical composition, antioxidant activities and total phenolic content of Arbutus andrachne L. (Fam. Ericaceae) (the Greek strawberry tree) fruits from Turkey. J. Food Compos. Anal. 2010, 23, 619-623. [CrossRef]

52. Hodges, D.M.; Lester, G.E.; Munro, K.D.; Toivonen, P.T.A. Oxidative stress: Importance for postharvest quality. HortScience 2004, 39, 924-929. [CrossRef]

53. Cao, S.; Yang, Z.; Zheng, Y. Effect of 1-methylcyclopene on senescence and quality maintenance of green bell pepper fruit during storage at $20^{\circ} \mathrm{C}$. Postharvest Biol. Technol. 2012, 70,1-6. [CrossRef]

54. Zheng, J.L.; Hu, L.Y.; Hu, K.D.; Wu, J.; Yang, F.; Zhang, H. Hydrogen sulfide alleviates senescence of fresh-cut apple by regulating antioxidant defense system and senescence-related gene expression. HortScience 2016, 51, 152-158. [CrossRef]

55. Foyer, C.H.; Noctor, G. Ascorbate and glutathione: The heart of the redox hub. Plant Physiol. 2011, 155, 2-18. [CrossRef]

56. Salin, M.L. Chloroplast and mitochondrial mechanisms for protection against oxygen toxicity. Free Radic. Res. Commun. 1991, 13, 851-858. [CrossRef]

57. Zhang, D.; Xu, X.; Zhang, Z.; Jiang, G.; Feng, L.; Duan, X.; Jiang, Y. 6-Benzylaminopurine improves the quality of harvested litchi fruit. Postharvest Biol. Technol. 2018, 143, 137-142. [CrossRef]

58. Paliyath, G.; Droillard, M.J. The mechanisms of membrane deterioration and disassembly during senescence. Plant Physiol. Biochem. 1992, 30, 789-812.

59. Cheema, A.; Padmanabhan, P.; Amer, A.; Parry, M.J.; Lim, L.T.; Subramanian, J.; Paliyath, G. Postharvest hexanal vapor treatment delays ripening and enhances shelf life of greenhouse grown sweet bell pepper (Capsicum annum L.). Postharvest Biol. Technol. 2018, 136, 80-89. [CrossRef]

60. Ali, S.; Khan, A.S.; Malik, A.U. Postharvest L-cysteine application delayed pericarp browning, suppressed lipid peroxidation and maintained antioxidative activities of litchi fruit. Postharvest Biol. Technol. 2016, 121, 135-142. [CrossRef]

61. Marangoni, A.G.; Palma, T.; Stanley, D.W. Membrane effects in postharvest physiology. Postharvest Biol. Technol. 1996, 7, 193-217. [CrossRef]

62. Kris-Etherton, P.; Hecker, K.D.; Bonanome, A.; Coval, S.M.; Binkoski, A.E.; Hilpert, K.F.; Griel, A.E.; Etherton, T.D. Bioactive compounds in foods: Their role in the prevention of cardiovascular disease and cancer. Am. J. Med. 2002, 113, 71-88. [CrossRef]

63. Materska, M. Bioactive phenolics of fresh and freeze-dried sweet and semispicy pepper fruits (Capsicum annuum L.). J. Funct. Foods 2014, 7, 269-277. [CrossRef]

64. Sachadyn-Król, M.; Materska, M.; Chilczuk, B.; Karaś, M.; Jakubczyk, A.; Perucka, I.; Jackowska, I. Ozone-induced changes in the content of bioactive compounds and enzyme activity during storage of pepper fruits. Food Chem. 2016, 211, 59-67. [CrossRef] [PubMed]

65. Valerio, F.; Mezzapesa, G.; Ghannouchi, A.; Mondelli, D.; Logrieco, A.; Perrino, E. Characterization and Antimicrobial Properties of Essential Oils from Four Wild Taxa of Lamiaceae Family Growing in Apulia. Agronomy 2021, 11, 1431. [CrossRef]

66. Vermerris, W.; Nicholson, R. The role of phenols in plant defense. In Phenolic Compound Biochemistry; Springer: Dordrecht, The Netherlands, 2008; pp. 211-234.

67. Kulbat, K. The role of phenolic compounds in plant resistance. Biotechnol. Food Sci. 2016, 80, 97-108.

68. Wada, L.; Ou, B. Antioxidant activity and phenolic content of Oregon cranberries. J. Agric. Food Chem. 2002, 50, 3495-3500. [CrossRef] [PubMed]

69. Pérez-Ambrocio, A.; Guerrero-Beltrán, J.A.; Aparicio-Fernández, X.; Ávila-Sosa, R.; Hernández-Carranza, P.; Cid-Pérez, S.; Ochoa-Velasco, C.E. Effect of blue and ultraviolet-C light irradiation on bioactive compounds and antioxidant capacity of habanero pepper (Capsicum chinense) during refrigeration storage. Postharvest Biol. Technol. 2018, 135, 19-26. [CrossRef] 